\title{
WUNDERLICH REVISITED: NEW LIMITS ON JUDICIAL REVIEW OF ADMINISTRATIVE DETERMINATION OF GOVERNMENT CONTRACT DISPUTES
}

\author{
FrankLiN M. Schultz*
}

\section{INTRODUCTION}

Eighty-five years ago in Kihlberg $v$. United States, ${ }^{1}$ a noted jurist, Justice John Marshall Harlan, laid down a basic principle of government contract law: where both parties to a government contract have entrusted the agent of one, the government's contracting officer, with the power to arbitrate and settle disputes arising between the parties under the contract, the contracting officer's decision shall be final and not subject to being upset by a court unless he is proved to have acted fraudulently or to have been so grossly mistaken as necessarily to imply bad faith, or unless it is established that he failed to exercise an honest judgment. ${ }^{2}$ Last year in United States $v$. Bianchi, ${ }^{3}$ the Supreme Court, speaking through another Justice John Marshall Harlan, the former's grandson, has further limited a court's discretion to upset such a final decision by restricting judicial review to the record made before an administrative appeals board (which presently hears an appeal from the contracting officer's decision) and at the same time prohibiting either party to introduce in the review proceedings any de novo evidence outside the administrative record.

During the eighty-five years between Kihlberg and Bianchi, some interesting legal history has been made..$^{4}$ At least since 1878 when Kihlberg was decided, the government's standard device for settling disputes with private contractors has been the finality or disputes clause, which is now boiler plate in its supply and construction contracts. ${ }^{5}$ By accepting the disputes clause as part of the contract, as of course he

* B.A. 1939, LI.B. I942, Yale University. Member of the District of Columbia bar. Chairman, Agency Adjudication Committee, Section of Administrative Law, American Bar Association. Formerly Associate Professor of Law, Indiana University School of Law and Lecturer in Law, George Washington University.

${ }^{2} 97$ U.S. 398 ( 1878 ).

a In Kihlberg the Court upheld a contract clause which made the determination of a chief district quartermaster binding as to the distances which governed the contractor's claims for transportation services. The Kihlberg doctrine was further spelled out in Martinsburg \& P.R.R. v. March, Ir 4 U.S. 549 ( 1885 ).

373 U.S. 709 (1963).

'In an earlier article I canvassed this history through 1953; see Schultz, Proposed Changes in Government Contract Disputes Settlement: The Legislative Battle Over the Wunderlich Case, 67 Harv. L. REv. 217 (1953).

5 The standard disputes clause included in Bianchi's contract read:

"Except as otherwise specifically provided in this contract, all disputes concerning questions of fact arising under this contract shall be decided by the contracting officer subject to written appeal by the contractor within 30 days to the head of the department concerned or his duly authorized representative, whose decision shall be final and conclusive upon the parties thereto. In the meantime the contractor shall diligently proceed with the work as directed." 
must, the contractor agrees that the contracting officer shall have the sole power to decide all disputes concerning questions of fact ${ }^{6}$ arising under operative contract clauses such as "changes" or "changed conditions," subject only to a written appeal to the department head or his duly authorized representative, whose decision shall be final and conclusive upon the parties; ${ }^{7}$ the contractor further agrees that, pending resolution of any dispute, "he will diligently proceed with the work as directed." Although the contractor thus contractually waives further appeal to the courts from an adverse departmental decision, the courts have continuously made limited review available, presumably on the theory implicit in Kihlberg that a party to the contract occupying the position of an impartial third party is not necessarily immune from committing fraud or making a gross mistake tantamount to bad faith or from plain dishonesty. But both the Supreme Court and the Court of Claims, the nisi prius court most concerned with deciding these matters, have had difficulty fitting difficult fact situations into the Kihlberg scope of review formula. In a number of cases prior to I95I the Court of Claims eroded the Kihlberg formula to the point where the decision of the contracting officer or departmental board was reversible if it were found to be "arbitrary," "capricious," or even "grossly erroneous." In I95I in United States v. Wunderlich," the Supreme Court, apparently annoyed by the Court of Claim's refusal to follow the strict Kihlberg formula, rejected arbitrariness or capriciousness as grounds for review and narrowed the scope of judicial review of a contracting officer's final decision to a single ground: allegation and proof of actual fraud. As Justice Minton put it for the Court, "By fraud, we mean conscious wrongdoing, an intention to cheat or be dishonest.... If the standard of fraud that we adhere to is too limited that is a matter for Congress."10

\section{THE Wundertich Act}

Taking Justice Minton's cue, and prodded by the strong reaction from aroused contractors who correctly read the Wunderlich decision as effectively foreclosing any judicial review, ${ }^{11}$ Congress embarked on a legislative investigation of this "arbitral process." A number of bills were introduced. Hearings were held before committees of both houses of Congress; ${ }^{12}$ representatives of private contractors and construction trade associations assailed the Wunderlich decision in the strongest

- Since 1954 limited to disputes concerning questions of fact by $\$ 2$ of the Wunderlich Act, 68 Stat. 8 I (I954), 4I U.S.C. $\$ 322$ (I958), which prohibits the inclusion in the disputes clause of any provision reserving to government officials the right to make final determinations of legal questions. 'This provision had been sanctioned in United States v. Moorman, 338 U.S. 457 (1950).

7 The contractor must exhaust this administrative remedy before going to court; see United States v. Blair, 32 I U.S. 730, 734-37 (I944).

${ }^{8}$ See Braucher, Arbitration Under Government Contracts, I7 LaW \& ConTEMP. ProB. 473, 496.99 (1952).

342 U.S. 98 (I95I).

${ }^{10} \mathrm{Id}$. at 100.

${ }^{11}$ See Palace Corp. v. United States, 124 Ct. Cls. 545, 549 (I952).

${ }_{12}$ Hearings Before Subcommittee of the Senate Committee on the Judiciary on S. 2487, 82d Cong., $2 d$ Sess. (1952); Hearings Before Subcommittee No. I of the House Judiciary Committee on H.R. 1839, S. 24, H.R. $3^{6} 6_{34}$ and H.R. $6946,83 \mathrm{~d}$ Cong., Ist and 2nd Sess. (1953-54). 
terms, often borrowing language from Justice Douglas' trenchant dissent; ${ }^{13}$ the American Bar Association protested the decision, recommending that review be subjected to the standards of the Administrative Procedure Act. ${ }^{14}$ Somewhat surprisingly, instead of entering the expected defense of the status quo, the procurement agencies (the Defense Department and the General Services Administration) expressed dissatisfaction with the Wunderlich decision and agreed to liberalize the language of the disputes clause. The Comptroller General, concerned that Wunderlich would restrict his own power to scrutinize the Board's decisions, favored legislative change, and took the lead in drafting the compromise legislation finally enacted. Only the Department of Justice opposed any change in the status quo.

The result of this considerable legislative effort was the Wunderlich Act, ${ }^{15}$ which provides in substance that a departmental decision on a question of fact arising under the disputes clause shall be final and conclusive "unless the same is fraudulent or capricious or arbitrary or so grossly erroneous as necessarily to imply bad faith or is not supported by substantial evidence."

As the accompanying House Report notes, the legislation had as its main purpose overcoming the effect of the Wunderlich decision. It restored the pre-Wunderlich standards of review based on arbitrariness and capriciousness and broadened the fraud standard once again to include gross mistake tantamount to bad faith. But it also-and this was its novel aspect-adopted "the additional standard that the administrative decision must be supported by substantial evidence," a standard which it borrowed from the Administrative Procedure Act and the basic federal labor regulation legislation. ${ }^{16}$ The Report noted that

the inclusion of the standard not supported by substantial evidence should also correct ... [a] condition arising out of the lack of uniformity between the various departments and agencies concerned in the appellate hearing procedures under the disputes clause ...

\footnotetext{
${ }^{13}$ United States v. Wunderlich, 342 U.S. 98, xoI (I95I): “. . . the rule we announce . . . makes a tyrant out of every contracting officer. ..."

It 60 Stat. 243 (1946), 5 U.S.C. $\$$ roor (x952).

I5 68 Stat. 8I (I954), 4 I U.S.C. $\$ \$ 32$ I-22 (I958). Section 321 provides:

"No provision of any contract entered into by the United States, relating to the finality or conclusiveness of any decision of the head of any department or agency or his duly authorized representative or board in a dispute involving a question arising under such contract, shall be pleaded in any suit now filed or to be filed as limiting judicial review of any such decision to cases where fraud by such official or his said representative or board is alleged: Provided, however, That any such decision shall be final and conclusive unless the same is fraudulent or capricious or arbitrary or so grossly erroneous as necessarily to imply bad faith, or is not supported by substantial evidence."

Section 322 provides:

"No Government contract shall contain a provision making final on a question of law the decision of any administrative official, representative, or board."

${ }^{10}$ House Comm. on the Judiciary, Finality Clauses in Government Contracts, H.R. REP. No. 1380, 83d Cong., $2 d$ Sess. 4 (I954) [hereinafter cited as House ReporT], which stated:

"The proposed amendment also adopts the additional standard that the administrative decision must be supported by substantial evidence. The requirement that administrative action be supported by substantial evidence is found in the Administrative Procedure Act, supra. As understood by the committee and as interpreted by the Supreme Court in Edison Company $v$. National Labor Relations Board (305 U.S. 197, 229), 'substantial evidence' means 'such relevant evidence as a reasonable mind might accept as adequate to support a conclusion'."
} 
[so] that the records of hearing officers will hereafter contain all the testimony and the evidence upon which they have relied in making their decisions.

The Report adds,

It would not be possible to justify the retention of the finality clauses in Government contracts unless the hearing procedures were conducted in such a way as to require each party to present openly its side of the controversy and afford an opportunity of rebuttal.17

While the House Report suggests that one reason for inclusion in the Wunderlich statute of the additional "substantial evidence" test was to require the decisions of departmental boards to be made "on the record," a fair reading of the congressional testimony reveals that administrative due process was not a central issue before Congress. The congressmen who considered the proposed legislation were mainly concerned with restoring the pre-Wunderlich standards of review so as to provide a genuine escape from possible arbitrariness and capriciousness on the part of the government officers entrusted with the ultimate authority to decide disputes. ${ }^{18}$ Moreover, while there was, as noted, some concern about the lack of administrative due process at the departmental level, the hearings do not reflect any significant concern with the Court of Claims' procedure for hearing and deciding cases brought by contractors who had been unsuccessful before the departmental boards, the issue before the Supreme Court in Bianchi.

\section{The Court of Claims' Construction of the Wunderlich Act}

Hence, it was not surprising that when the Court of Claims was first faced with the question of how its trial commissioners should conduct the trial of contract disputes subject to the Wunderlich Act, it chose to continue its pre-Wunderlich practice of having such cases tried de novo.

In Volentine and Littleton $v$. United States, ${ }^{10}$ the plaintiff-contractor introduced and relied upon de novo evidence rather than the administrative record. The government objected that the Wunderlich Act required the contractor to restrict his evidence to the record made before the departmental board, contending that " $[\mathrm{a}$ court] cannot apply the derogatory language which the statute uses to the depart-

${ }^{2 \tau}$ Id. at $4-5$.

${ }^{18}$ In fact, several congressmen expressed concern over the somewhat strained position taken by the Department of Justice that the Wunderlich decision did not narrow the prior standard of review, and for this reason may have favored the addition of the "substantial evidence" test to remove any doubts that they intended to undo the effects of Wunderlich. See testimony of Phillips, in House Hearings, supra note 12, at 45 et seq.; see testimony of Schultz, id. at II2:

'Mr. Hyde. If you omit the substantial evidence test, however, are you not likely in view of some of the language in the Wunderlich case to still be in the same spot we are under the Wunderlich case?

"Mr. Schultz. I do not think so, sir.

"Mr. Hyde. Did you hear Mr. Phillips yesterday from the Department of Justice?

"Mr. Schultz. Yes, sir, I did.

"Mr. Hyde. The way they construe the Wunderlich case, it seems to me that the language 'fraud' or 'grossly erroneous necessarily to imply bad faith' are almost synonymous."

${ }_{10}$ I45 F. Supp. 952 (Ct. Cl. r956). Judge Madden wrote the opinion; Laramore, J. dissented. In an earlier decision, Wagner Whirler \& Derrick Corp. v. United States, I2r F. Supp. 664, 667 (Ct. Cl. 1954), the court intimated it would revert to its pre-Wunderlich practice. 
mental decision unless one knows the evidence on which the decision was based which might have been very different evidence from that reported in this court."20 While recognizing the logic of the government's position that the "substantial evidence" standard called for an appellate-type review limited to the administrative record, the Court of Claims could not square that logic with certain procedural difficulties. To start with, it was the court's view that the government's reading of the Wunderlich Act would require two trials instead of one-the first to determine whether on the basis of the record the administrative decision was "tolerable," i.e., supported by substantial evidence, and the second, a de novo trial on the merits in the event the administrative decision was found not to be tolerable and therefore no longer "final" under the disputes clause. Perhaps even more persuasive than the burden of conducting two trials was the court's belief that, since the "so-called 'administrative record" " was in many cases "a mythical entity," there being no statutory provision requiring an administrative proceeding, such a record would not be susceptible to normal appellate review. ${ }^{21}$ Accordingly, the court did not require the contractor to introduce and rely solely on the administrative record but laid down a court rule permitting a de novo proceeding.

The Justice Department did not seek certiorari in Volentine. However, when the court decided the identical issue a year later in Fehlhaber Corp. v. United States, it unsuccessfully petitioned the Supreme Court for certiorari. ${ }^{22}$ Thus, up to the time of the Supreme Court's June, 1963 decision in Bianchi, the Court of Claims did not require the plaintiff contractor to introduce the administrative record, and permitted introduction by either party of unlimited evidence de novo. On the basis of a new record containing all evidence thus introduced (which might or might not include the administrative record) the trial commissioner then made findings of fact and determined whether the departmental decision met the Wunderlich Act's standards, subject only to a final review by the full court. ${ }^{23}$

On the uther hand, during the same period several district courts and four different circuit courts of appeal restricted court review to the administrative record. Noting that "the law is quite unsettled," and that "the legislative history of the Wunderlich Act is inconclusive," but undoubtedly familiar with reviewing decisions of regulatory agencies exclusively on a record under the "substantial evidence" test, the Second Circuit in Allied Paint \& Color Works approved the district

${ }^{20} 145$ F. Supp. at 954 .

21 Ibid.:

"... The head of the department may make the decision on appeal personally or may entrust anyone else to make it for him. Whoever makes it has no power to put witnesses under oath or to compel the attendance of witnesses or the production of documents. There may or may not be a transcript of the oral testimony. The deciding officer may, and even in the departments maintaining the most formal procedures, does, search out and consult other documents which, it occurs to him, would be enlightening, and without regard to the presence or absence of the claimant."

22 15I F. Supp. 8I7 (Ct. Cl. 1957), cert. denied, 355 U.S. 877 (1957).

${ }^{33}$ But during the period the court on occasion took a middle ground, see Harrison, Eight Years after Wunderlich-Confusion in the Courts, 28 GEo. WASt. L. REv. 56r (I960); P.L.S. Coat \& Suit Corp. v. United States, I80 F. Supp. 400 (Ct. Cl. I960). 
court's refusal to take additional testimony and affirmed its action in confining review to the administrative record. ${ }^{24}$

\section{The Bianchi Decision}

It was this conflict between the Court of Claims and the various circuit and district courts which finally persuaded the Supreme Court to grant the government's petition for certiorari in Bianchi.

In 1946 Bianchi contracted to build a water diversion tunnel as part of an Army Corps of Engineers flood-control dam. After the tunnel had been drilled but before it was lined, the contractor took the position that he was entitled to extra compensation under the standard changed conditions clause because permanent steel protection was needed throughout the tunnel to protect his workmen from extreme hazards, a need not foreseen in the contract documents. The contracting officer denied the claim and the contractor took a timely appeal under the disputes clause. In I948 after a one-day adversary hearing at which each side offered its evidence and had an opportunity for cross-examination, the Corps of Engineers Claims and Appeals Board resolved the conflicting evidence in the government's favor and denied the claims, holding in substance that there was no unforeseen condition requiring the use of the permanent steel protection throughout the tunnel which the contractor had elected to install at its own expense.

Six years later the contractor brought suit in the Court of Claims for breach of contract, alleging that the decisions of the contracting officer and the Board did not satisfy the Wunderlich Act standards. Before the trial commissioner the government once again took the position that on the question of liability no evidence was admissible other than the record before the Board. As expected, the trial commissioner overruled the government and admitted evidence de novo, including a substantial amount which had not been before the Board (the contractor introduced four witnesses before the Board, fifteen before the commissioner), and subsequently made findings in favor of the contractor. On review the Court of Claims accepted the commissioner's findings and conclusions and ruled that "on consideration of all the evidence, the contracting officer's decision [as affirmed by the Board] cannot be said to have substantial support," and thus "does not have finality."25 On the question whether it was limited in its consideration to the evidence before the Board, the court, while recognizing the "logical weaknesses," adhered to its former position in Volentine and sanctioned the admission of the de novo evidence.

The Supreme Court granted certiorari "to resolve a conflict among the lower courts on the important question of the kind of judicial proceeding to be afforded in

${ }^{24}$ Allied Paint \& Color Works, Inc. v. United States, 309 F.2d, r33, r37-38 (2d Cir. I962), cert. denied, 375 U.S. $81_{3}$ ( $(963)$; the decisions in the other circuits were Lowell O. West Lumber Sales v. United States, 270 F.2d I2 (9th Cir. I959); Hoffman v. United States, 276 F.2d 199 (roth Cir. I960); Wclls \& Wells v. United States, 269 F.2d 412 (8th Cir. 1959); see Harrison, stlpra note 23, at 567-7x.

${ }^{25}$ Bianchi v. United States, I69 F. Supp. 514, 5I7 (Ct. Cl. I959). 
cases governed by the Wunderlich Act,"26 and in a seven-to-two decision reversed the Court of Claims.

Bianchi, Justice Harlan began, had sued the United States under the Tucker Act, ${ }^{27}$ on a breach of contract theory. Ordinarily, as to questions of fact arising in such a suit, the function of the court is to receive evidence and make appropriate findings as the disputed facts. But the Court noted that since Kihlberg it had recognized the "validity of clauses in government contracts delegating to government employees the authority to make determinations of disputed questions of fact" and requiring such determinations to be given conclusive effect in any subsequent suit in the absence of fraud or bad faith. In this connection

. . . the function of the Court of Claims in matters governed by "disputes" clauses was in effect to give an extremely limited review of the administrative decision, and although the scope of review was somewhat expanded by the court over the years, it was expressly restricted in United States $v$. Wunderlich. ... .

The Court then pointed out that Bianchi had not argued that his underlying controversy was beyond the scope of the disputes clause or not governed by the language of the Wunderlich statute. The sole issue was whether, aside from questions of fraud which normally required receipt of evidence outside the administrative record, the Court of Claims was limited to the administrative record with respect to the underlying controversy or was free to take new evidence. Examining the language of the Wunderlich statute (including its designation as an act "to permit review") and its legislative history, particularly the House Report, the Court concluded that it was Congress' intent that the Court of Claims should limit its review to the administrative record.

Nor was the Court influenced by the procedural difficulties which had bothered the Court of Claims in Volentine. Justice Harlan's answer was that "the function of reviewing an administrative decision can be and frequently is performed by a court of original jurisdiction as well as by an appellate tribunal." Further, he pointed out, even where Congress had simply provided for review without setting forth the standards to be used or the procedures to be followed, the Supreme Court had held that a court's consideration must be confined to the administrative record. ${ }^{29}$

Moreover, the standards of review adopted in the Wunderlich Act-"arbitrary," "capricious," and "not supported by substantial evidence"-have frequently been used by Congress and have consistently been associated with a review limited to the administrative record. The term "substantial evidence" in particular has become a term of art to describe the basis on which an administrative record is to be judged by a reviewing court. This standard goes to the reasonableness of what the agency did on the basis of the evidence

20373 U.S. at 712.

${ }_{27} 28$ U.S.C. \$ I 49 I (1958).

${ }^{28} 373$ U.S. at 7 I3.

${ }^{20}$ Id. at 7I5, citing Tagg Bros. \& Moorhead v. United States, 280 U.S. 420 (I929), and National Broadcasting Co. v. United States, 319 U.S. Igo, 227 (I943). 
before it, for a decision may be supported by substantial evidence even though it could be refuted by other evidence that was not presented to the decision-making body. ${ }^{30}$

The Court then noted the explicit references in the House Report to the Administrative Procedure Act and decisions based on the Taft-Hartley Act and the Report's caveat that it would "not be possible to justify the retention of the finality clauses in government contracts unless the hearing procedures were conducted in such a way as to require each party to present openly its side of the controversy and afford an opportunity of rebuttal."31 This clearly expressed legislative purpose of having a full-fledged adversary proceeding, the Court said, would be "frustrated if either side were free to withhold evidence at the administrative level and then to introduce it in a judicial proceeding," implying that this is what happened in Bianchi. Moreover, the Court deplored such a procedure as a "needless duplication of evidentiary hearings and a heavy additional burden in time and expense required to bring litigation to an end."32

Next, the Court dealt with the contention that "if the administrative record is defective or inadequate, or reveals the commission of some procedural error ... the Court of Claims had no power to remand a case such as this to the department concerned ..." but "can only hold an evidentiary hearing and proceed to judgment." ${ }^{\text {s }}$ The Court gave two answers to this contention. First, in certain situations the Court of Claims would be warranted, on the basis of the administrative record, in granting the contractor judgment without need for further administrative action; second, if it believed that the existing record did not warrant such a radical remedy but that the departmental determination could not be sustained under the Wunderlich Act standards, the Court could stay its own proceedings pending further action before the departmental board. ${ }^{34}$ Moreover, the Court noted that "such a stay would certainly be justified where the department had failed to make adequate provision for a record that could be subjected to judicial scrutiny, for it was clearly part of the legislative purpose to achieve uniformity in this respect."35 Finally, while apparently recognizing that the Court of Claims had no statutory power (comparable to that of other federal courts) to correct errors in a record by the process of remand, the Court stated that in any case where, after the court issued a stay, "the department failed to remedy the particular substantive or procedural defect or

${ }^{80} 373$ U.S. at 715.

${ }^{81}$ House REPORT 5.

32 U.S. at 7 IT.

${ }^{33} 373$ U.S. at 717. The contention relies on United States v. Jones, 336 U.S. 64I, 670-71 (1949), where the Court held that, "in view of the fact that the Court of Claims has jurisdiction only to render a money judgment against the United States and none to remand" to the Interstate Commerce Commission for further consideration, the Court lacked jurisdiction to enter a final judgment.

${ }^{\text {s4 }}$ Citing Pennsylvania R.R. v. United States, 363 U.S. 202, 206 (1960), where the Court held it was error for the Court of Claims to render judgment on the basis of the Interstate Commerce Commission order "without suspending its proceedings to await determination of the validity of that order by the Pennsylvania District Court." See also United States v. Western Pac. R.R., 352 U.S. 59 (1956).

${ }^{85} 373$ U.S. at 718. 
inadequacy, the sanction of judgment for the contractor would always be available to the court." ${ }^{36}$

Justices Douglas and Stewart dissented on the ground that the departmental decision was "capricious or arbitrary" in that evidence was considered by the Board which the claimant did not see and which he had no opportunity to refute. After describing the circumstances surrounding the Board's consideration of this allegedly ex parte evidence (which the majority did not consider properly within its certiorari grant), Justice Douglas noted that the alleged irregularity proved Judge Madden's charge in Volentine that ". . . the so-called 'administrative record' is in many cases a 'mythical entity" "; in Justice Douglas' view the Court was dealing with "subnormal administrative procedures." Conceding that a hearing before the Board contained many protective features, it lacked, he said, some of the safeguards normally accorded claimants in administrative proceedings subject to sections five and seven of the Administrative Procedure Act. ${ }^{37}$ Had section seven been applicable, he said, it would have made reliance by the Board on the ex parte hearsay statement reversible error. Justice Douglas further noted that a remand to the Board to determine if it had acted capriciously or arbitrarily was "obviously inappropriate" since it was the court, not the Board, which should judge the Board's conduct. For this reason he believed "a de novo hearing was permissible before the Court of Claims."

\section{Implications of Bianchi for the CouRt of Claims}

The Court of Claims thus found itself the legatee of a new procedural rule and of a number of difficult problems not raised in Bianchi. In two recent decisions, Stein Bros. Mfg. Co. v. United States, ${ }^{39}$ and WPC Enterprises, Inc.v. United States, ${ }^{40}$ the court has made a beginning at finding workable solutions to some of these problems.

In Stein Brothers, the government had failed to object to the introduction or consideration of certain de novo evidence before the trial commissioner, as it had done in Bianchi. After the Supreme Court decided Bianchi, the government raised an objection to certain findings based on this evidence. But the court held that, by failing to make timely objection, the government had waived its right to exclude this evidence from the court's consideration. ${ }^{41}$

${ }^{30}$ Ibid.

${ }^{37}$ "The exemption from $\S_{7}$ is highlighted in this case. That section provides in part: Every party shall have the right to present his case or defense by oral or documentary evidence, to submit rebuttal evidence, and to conduct such cross-examination as may be required for a full and true disclosure of the facts." 373 U.S. at 721 .

${ }^{38} 373$ U.S. at 7 I 9.

${ }^{30}$ Ct. Cl., No. $389-59$, decided July I2, I963.

${ }^{40} \mathrm{Ct}$. Cl., No. 256-59, decided Oct. $1 \mathrm{I}, \mathrm{\text {r }} 963$.

«I The theory behind this apparent departure from Bianchi was, first, that the Wunderlich Act was not phrased in jurisdictional terms and, second, that the Supreme Court in Bianchi did not make a jurisdictional holding on the exclusion of de novo evidence, but indicated (by the two cases it cited to demonstrate that a court of original jurisdiction can perform the function of reviewing an administrative decision on the record made before an agency) that the problem is "evidential or procedural and 
If, by failing to object, the government (or the contractor) may thus waive the Bianchi exclusionary rule on de novo evidence, it would be a logical extension for the court to permit both parties to stipulate that de novo evidence may be introduced to supplement the administrative record. Since Bianchi precludes the government as well as the contractor from supplementing the administrative record, such a stipulation procedure could benefit not only the contractor but also the Department of Justice, particularly in cases where the Department believed that its position had not been adequately presented at the agency level.

What course, however, should the court take where neither the contracting officer nor the board reached the determination of adequate compensation and the court subsequently found the government liable for breach? Does Bianchi require the court to suspend the proceeding until the plaintiff returns to the Board, moves to reopen the proceeding, and pleads and proves his case for compensation? In Stein Brothers, the court's answer was "No." Its decision to send the case to the trial commissioner rather than the Board for a determination of proper compensation did not, it said, run counter to the Wunderlich Act as construed by Bianchi since the parties had agreed that the Board would determine compensation only if the contractor prevailed on the issue of liability. Since the contractor had not prevailed, the Board was not required to make a factual determination on compensation, which could be binding on the court. Accordingly the court was free to do so de novo. ${ }^{42}$

WPC Enterprises, the other recent Court of Claims case applying Bianchi, in-

not jurisdictional." The two cases were Tagg Bros. \& Moorhead v. United States, supra note 29, which characterizes as a "question of practice" the issue whether de novo evidence should be introduced in the course of judicial review (280 U.S. at 442); and National Broadcasting Co. v. United States, supra note 29, where the Court called this "a procedural point." (319 U.S. at 227.) In Stein Bros., supra note 39 , the Court also pointed out there is no more reason to consider the limitations of the Wunderlich Act non-waivable than other rules of procedure, practice, evidence or rules of substantive law, such as the important defense of failure to exhaust an administrative remedy, which must be raised if reliance is to be placed on it.

The opposite fact situation arose in Hunt and Willett, Inc. v. United States, Ct. Cl. No. 376-58, now pending on exceptions from the commissioner's report. There before the commissioner the plaintiff had relied exclusively on the administrative record to establish liability but, over the plaintiff's objection, the government had been permitted to introduce de novo evidence. The commissioner's report, which was unfavorable to plaintiff, was based in large part upon the de novo testimony offered by the government. The plaintiff has filed exceptions claiming that in admitting the de novo evidence the commissioner acted contrary to the principle of the Bianchi case. Since here, unlike Stein Bros., one of the parties (the plaintiff) did object to the introduction of de novo evidence, the Court again will have to decide whether Bianchi operates retroactively to exclude such evidence.

${ }^{2}$ The court added that to return the case at its present stage to the Army for findings on the question of compensation would only add delay which the Supreme Court had sought to diminish by its ruling; and that, unlike a court of appeals reviewing an administrative decision, the Court of Claims and the district courts were well equipped to take and consider evidence on damage questions not previously decided by the administrative boards. Stein Bros., slip opinion, p. 5. Note that on the remand of Bianchi from the Supreme Court, the trial commissioner, confining the trial to a review of the administrative record, found that the findings and decision of the Board lacked substantial cvidence, and therefore recommended judgment for Bianchi on the question of liability. However, relying on the Supreme Court's language in Bianchi, and apparently contrary to Stein Bros., the trial commissioner stayed the proceeding for six months to enable the Board or contracting officer to determine the amount of compensation. Bianchi v. United States, Ct. Cl. No. 446-54, commissioner's determination filed Nov. 4, 1963. 
volved a mutual misunderstanding of a contract provision, picturesquely described by Judge Davis as "one prolonged minuet of cross purposes." ${ }^{\text {"43 }}$ It posed the question whether a government contract required a contractor to obtain the component parts of a product being furnished the government from certain named suppliers or whether he was privileged to utilize identical components furnished by firms of the contractor's own choosing. After the contract was awarded the government insisted that the contractor had to furnish parts manufactured by named companies. The contractor complied but, claiming that the government's directive constituted a contractual "change order," unsuccessfully sought relief from the contracting officer and the Armed Services Board of Contract Appeals (ASBCA). The Board turned down the appeal on the ground that after submission of his bid but prior to the award the contractor had been advised of the government's position on what the pertinent contract provision meant and had acquiesced therein.

Relying on the theory of waiver enunciated in Stein Brothers, the court sanctioned the consideration by the trial commissioner of additional evidence presented by both sides on this disputed point, to which the government had failed to object until after Bianchi was decided.

In its opinion the court queried whether the Board's administrative findings on this point were entitled to any special weight under the Bianchi ruling and the Wunderlich Act. Assuming arguendo that they were, the court held they are not "final" under the act because they "lacked substantial support in the record as a whole." Then, reverting to Justice Harlan's first alternative for disposing of a board decision failing to meet the Wunderlich Act standards, ${ }^{44}$ the court concluded that "unconstrained by the administrative determination, we can make our own findings, from the whole record, on the issue of acceptance by one side of the other's view." 45 In other words, once having decided the Board's decision was not "final" under the Wunderlich Act, the court has ruled that it is released from the requirements of the disputes clause and can make independent findings and a determination. ${ }^{46}$

Also significant for future development of law under Bianchi is the court's statement that:

The holding that plaintiff acquiesced in the Government's interpretation, though a "factual" finding in one sense, is intimately related to the legal question of what was the

${ }^{\star S}$ Slip opinion, p. 8.

4373 U.S. at 7I7.

"WPC Enterprises, slip opinion, p. 8.

"Apparently Justice Harlan did not reach the question decided here. What Justice Harlan said ( 373 U.S. at $7 \mathrm{I} 7$ ) was that "if the administrative record is defective or inadequate, or reveals the commission of some prejudicial error," the Court might be "warranted, on the basis of the administrative record, in granting judgment for the contractor without need for further administrative action." (Emphasis added.) The Court apparently had in mind internal procedural defects, such as Bianchi alleged, rather than a lack of substantial evidence to support the Board's findings. But the Court of Claim's extension in WPC Enterprises seems justified. Otherwise, every reversal on the evidence would require a remand to the Board to make findings as directed by the court, and the result would be unnecessary delay and expense. 
contract the parties made between themselves; under the [Wunderlich] Act, all legal questions are to be resolved independently by the court, and under our prior decisions subordinate "factual" findings akin to those made here are wholly subsumed in the larger legal problem of contract interpretation. ... That is a problem which we shall doubtless have to meet again in other cases. ${ }^{47}$

While the Court of Claims seems to have resolved several basic questions, Bianchi left in its wake other knotty questions the Court of Claims has yet to answer.

Take, for one, the point of Justice Douglas' dissent, that the court, not the Board, should determine whether the Board's decision is "capricious" or "arbitrary" because it relied on ex parte evidence. If the contractor's charge of procedural irregularities is based on evidence outside the administrative record, how can the court determine the truth of this charge without first receiving the alleged evidence de novo? Yet this is what Bianchi, literally read, suggests a court cannot do. ${ }^{48}$ Would it not make better sense for a court to apply the same rule the majority conceded governs determination of questions of fraud: "receipt of evidence outside the administrative record for their resolution?" This would appear to hold equally true for offers of evidence allegedly wrongly excluded, demands for documents allegedly wrongly denied, or any other board ruling or infirmity, which, the contractor alleges, makes the Board's decision "capricious or arbitrary or so grossly erroneous as necessarily to imply bad faith." Will the Court of Claims construe Bianchi to permit the taking of de novo evidence in any of these eventualities, because it is the only workable solution?

To take another unresolved point, it seems fairly clear that, so long as the appeals boards remain exempt from the Administrative Procedure Act, the Court of Claims will be obliged to develop its own law of administrative due process, much as the Supreme Court did prior to 1946 in the Morgan cases, which established some minimum due process standards for a quasi-judicial proceeding. ${ }^{40}$

\footnotetext{
${ }^{47}$ WPC Enterprises, slip opinion, p. 7. While the Court thus postponed the troublesome problem of "what is fact and what is law" (See Birnbaum, Questions of Law and Fact and the Jurisdiction of the Armed Services Board of Contract Appeals, I9 FED. B. J. I20 (I959)), it gave a clear harbinger of its future attitude on this unresolved problem. To one uninitiated in Court of Claims niceties, it is surprising to learn that the resolution of the conflicting evidence regarding pre-award contract negotiations (including the witnesses' credibility) does not constitute a finding of facts, but is "subsumed" under a question of law and is therefore outside the disputes clause. Given the Court's present predilection, skillful practitioners can be expected to frame legal issues to "subsume" significant fact questions and avoid Bianchi's strict evidentiary requirement. See Wingate Construction Co. v. United States, Ct. Cl. No. $394-60$, decided Jan. 24, I964, where the court held that "since the issue before us is one of contract interpretation, it may well be that Bianchi ... does not preclude the admission of de novo evidence necessary to make a factual determination underlying the conclusion of law." Slip opinion, p. 7.

${ }^{8} 373$ U.S. at 7I4: "It is our conclusion that, apart from questions of fraud, determination of the finality to be attached to a departmental decision on a question arising under a 'disputes' clause must rest solely on consideration of the record before the department."

${ }^{40}$ Morgan v. United States, 298 U.S. 468 (I936); Morgan v. United States, 304 U.S. I (1938); sce Kenneth C. Davis, Administrative Law Treatise $\$ 109$ n.27 (1958). Prior to Bianchi the Court of Claims recognized the applicability of the Morgan cases to board proceedings. Climatic Rainwear v. United States, $88 \mathrm{~F}$. Supp. 415 (Ct. Cl. 1950) (quoting the first Morgan case, 298 U.S. at 481: "The one who decides must hear.").
} 
What, however, if the court discovers procedural or substantive irregularities which the non-statutory boards have no power to remedy? For example, assume that the contractor needs the testimony of a retired contracting officer whom the department can no longer compel to testify but who is unwilling to appear voluntarily. If this witness' testimony is vital to the contractor's proof and the board is powerless to compel him to testify, is the court left with Justice Harlan's unsatisfactory alternative of granting the contractor a default judgment? ${ }^{50}$

Again, suppose a board has dismissed an action on the ground that it is an action seeking damages for breach of contract for which the board under its charter has no authority to grant relief. Yet, involved in the action for breach may be important fact questions which the board could have determined but did not because the facts so determined would have constituted "sterile findings." sues in the Court of Claims, is that court required to stay the proceeding until such time as the board has determined the underlying factual issues, which the board for good reason previously had refrained from reaching? ${ }^{52}$ The common sense answer seems to be "No." Otherwise, would not the delays which Justice Harlan deplored be compounded?

There are no doubt other transitional problems which the Court of Claims will face while pre-Bianchi cases remain in its pipeline. Evidence to date would not suggest that the court will take a strict constructionist attitude on any of these Bianchi-related questions. ${ }^{53}$

${ }^{50} 373$ U.S. at 718 . In this connection it has been suggested that a department could invoke the little used power provided by 5 U.S.C. $\$ 94$ (x958), which provides:

\$94. Subpoenas to witnesses. Any head of a department or bureau in which a claim against the United States is properly pending may apply to any judge or clerk of any court of the United States, in any State, District, or Territory, to issue a subpoena for a witness being within the jurisdiction of such court, to appear at a time and place in the subpoena stated, before any officer authorized to take depositions to be used in the courts of the United States, there to give full and true answers to such written interrogatories and cross-interrogatories as may be submitted with the application, or to be orally examined and cross-examined upon the subject of such claim.

Apparently, on application of a department (but not a party), the district court could subpoena a reluctant retired contracting officer to have his deposition taken but not to attend the hearing or produce documentary evidence. It is noteworthy that in both Stein Bros. and WPC Enterprises, discussed stura, pp. 123-25, certain internal memoranda of government contracting officials first obtained in the court proceeding significantly influenced the court's decision to reverse the Board. See Stein Bros. slip opinion, p. 26 n.13:

"The documents quoted in findings 2I, 22 and 25 were not in the record before the ASBCA and were not known to plaintiff until produced by defendant in response to a subpoena duces tecum issued by the court."

${ }^{E 1}$ The phrase is ASBCA Chairman Spector's. See Simmel Industrie, ASBCA No. 6r4I (xg6r), 6x-I BCA I5229 \291\%. There the Board stated that, while the charter authorizes the Board to make findings of fact even if it lacks jurisdiction to make an award, the Board would not do so where no useful purpose would be served.

${ }^{60}$ See Stein Bros., slip opinion, p. 5, where the Court volunteered that "In cases in which the administrative authorities have failed or refused to determine a dispute which should have been decided under the disputes article of the contract, the courts have customarily made that determination for themselves," citing nine cases, all but one decisions of the Court of Claims.

${ }^{63}$ Hence it is highly improbable that the Court of Claims will accede to the position the government has recently taken that the Bianchi principle should be extended to an administrative record not subject to the disputes clause, in this case the findings of the Board for Correction of Military Records. See 
Implications of Bianchi for the Boards of Contract Appeais

If one thing is clear from Bianchi, it is that the Supreme Court conceived of a proceeding before a contract board under the disputes clause as a quasi-judicial hearing. As noted, Justice Harlan strongly suggests that the departments must "make adequate provision for a record that could be subjected to judicial scrutiny." He no doubt had in mind the kind of record with which the Supreme Court is familiar in reviewing decisions of independent regulatory agencies subject to the Administrative Procedure Act.5

But the boards are exempt from that act under section 2(a), which excludes from the operation of the Administrative Procedure Act "agencies composed of representatives of the parties ... to the disputes determined by them." Nevertheless, of the dozen boards which presently decide appeals under the disputes clause, ${ }^{60}$ several publish procedural rules which offer a formal type of hearing, including an exchange of pleadings, limited discovery, a pre-trial conference, formal introduction of documents, a transcript of the hearing, pre-hearing and post-hearing briefing, and oral argument. Probably the least formal proceeding is provided by the Board of Appeals in the Department of Commerce, which has published no rules; and the most formal proceeding is provided by the Armed Services Board of Contract Appeals in the Defense Department, which has detailed rules of procedure. ${ }^{57}$

It is doubtful, however, whether even an ASBCA proceeding satisfies the formality of an agency hearing subject to Administrative Procedure Act requirements. An ASBCA board member does not have all the hearing powers provided by section 7 (b) of the Act. While the board rules provide that the board member may administer oaths ${ }^{58}$ and cause depositions to be taken, he is without authority to permit depositions to be taken for purpose of discovery; ${ }^{59}$ he also lacks the necessary statutory authority to subpoena witnesses or compel production of documents. Further, he lacks the power provided by section 8(b) of the Administrative Procedure Act to afford the parties the opportunity to submit proposed findings and

Commissioner McConnaughey's memorandum opinion overruling the government's motion to strike de novo evidence in Stevens v. United States, Ct. Cl. No. 189-60, filed July 22, 1963.

373 U.S. at $7 \mp 8$.

${ }^{55}$ Also noteworthy is the fact that Justice Harlan thought it was "clearly part of the legislative purpose to achieve uniformity" with respect to providing the kind of a record which could be subject to judicial scrutiny. 373 U.S. at 718.

${ }^{50}$ See Ablard, A Survey of the Boards of Contract Appeal in the Federal Government and Their Authority to Decide Contract Disputes, 30 J.B.A.D.C. $64\left(196_{3}\right)$. Eight of the boards are in six departments of the executive and four are in four independent agencies.

${ }^{5 \tau}$ See ASBCA rules, revised July ${ }_{5} 5,1963,28$ Fed. Reg. 9348 (1963).

68 The boards have no statutory authority for administering the oath; as a substitute thercfor some presiding board members read 18 U.S.C. $\$ 287$ (1958) (False Claims Act) or 18 U.S.C. $\$$ roox (1958) (False Statements Act) to each witness when he takes the stand.

${ }^{59}$ Of the other eleven boards, half do not provide for discovery by rule. Federal Maritime Comm'n v. Anglo-Canadian Shipping Co., U.S. Dist. Ct., N.D. Cal., I4 PIke \& Fischer Ad. L.2d 220 (Aug. 1963), raises the interesting question whether legislation may not be needed to confer discovery powers on the boards. The district court there held that the Federal Maritime Commission had no authority to promulgate a rule granting discovery power at the pre-hearing stage of a proceeding similar to powcr granted to the federal courts by the Federal Rules of Civil Procedure. 
conclusions or exceptions to a recommended decision. ${ }^{60}$ Finally, the ASBCA rules do not provide for disqualification of a presiding officer, ${ }^{61}$ or, of most importance, guarantee that "the testimony and the exhibits will constitute the exclusive record for decision."

On the other hand, while the board procedures may be, as Justice Douglas claims, "subnormal," if the Administrative Procedure Act is the norm, it is unfair to characterize the record, as does Justice Douglas, a "mythical entity." Since the board procedures were brought sharply to public attention at the time of the Wunderlich Act hearings, there have been notable improvements in the board proceedings. ${ }^{63}$ For example, there has been a decided trend toward giving the boards final authority in no respect reviewable by the department head. ${ }^{64}$ While a hearing may be conducted before a single board member, the decision is now often made by a majority of the board or panel, and most board members are full time. In most instances the hearing before the board is de novo (neither party being bound by the contracting officer's findings), as the Wunderlich Act appears to have contemplated. Finally, and here there may be doubters, it has been favorably noted that all or a majority of the members of each board are attorneys. ${ }^{65}$

There is one major respect, however, in which even the most formal board proceeding departs from the Administrative Procedure Act, and that is with respect to the status of the hearing officer. Some boards may draft a hearing officer from a bureau or division such as the General Counsel's office without conferring on the draftee any quasi-judicial status. And, for some boards the function of a hearing officer is a part time or additional duty. As an employee of the department the hearing officer has no permanent tenure. ${ }^{66}$ Steps to improve the status of the hearing officer could be taken. One would be a board rule requiring that, except for good cause shown, "he who hears must decide," a practice from which various boards have in the past departed. ${ }^{67}$

${ }^{\circ 0}$ Procedures which may facilitate the joinder and resolution of law and fact issues.

o1 Administrative Procedure Act, $\$ 7$ (a).

${ }^{02} 1 d . \$ 7(\mathrm{~d})$.

${ }^{03}$ See Hearings Before the Subcomm. for Special Investigations of the House Con.m. on Armed Services on H. Res. 67, Inquiry into the Administration and Operation of the Armed Services Board of Contract Appeals, 85th Cong., 2d Sess. (x958).

${ }^{\circ 4}$ See Ablard, supra note 56, at 64 . In 1958 the Contract Appeals Board of the General Services Administration, the second largest procurement agency, was delegated final authority by the Administrator.

${ }^{05}$ It is also noteworthy that practically all of the boards now make their decisions available to practitioners and the decisions of most of the boards are unofficially published.

${ }^{\circ 0}$ But even here there have been several interesting innovations. The Post Office Department Board consists of the Department's statutory Judicial Offcer, who serves as chairman, and two Civil Service hearing examiners. Recently the Atomic Energy Commission has provided for contract appeals to be decided by a Civil Service hearing examiner. Such an examiner is, of course, precluded by the Administrative Procedure Act from consulting with any Commission personnel in arriving at his decision and the only review of his decision is a limited certiorari to the full Commission. See Ablard, supra note 56, at 67,70 .

${ }^{07}$ See Anthony P. Miller, Inc. v. United States, Ct. Cls. No. 3-62, decided April 5, 1963, slip opinion, p. 19 n.II: "Without merit is plaintiff's contention that the ASBCA decision is invalid because the member who heard the evidence did not decide the case. There is no applicable rule stating that 
Undoubtedly Bianchi will call for another round of self-examinations by the boards. While much can be done internally to improve the independent status of the board members, in the final analysis no decision is better than the integrity of the individual who makes it, whether he wears black robes or a business suit. With respect to the improvement of their procedures, the boards can only go so far. If the contractor is to have a full-dress quasi-judicial hearing, and if the record so made is to be protected, consideration must be given to enabling legislation. Across-theboard statutory subpoena power would be an easy first step. ${ }^{68}$ Whether the boards should be brought under the Administrative Procedure Act, and to what extent, is a question which needs considerable study. ${ }^{69}$

A reluctance to "judicialize" the contract procedure is nonetheless understandable. To some critics, including retired Judge Madden, ${ }^{70}$ the disputes procedure is simply the final step in the long-term negotiation of a contract. Its function is to provide procurement officials with the kind of opportunity a corporate officer of a large corporation has to review the decision of his subordinate on a contract matter. It gives the responsible officer who is removed from the immediate controversy the authority to correct errors made by his subordinate. It also affords a speedy, inexpensive remedy which many contractors prefer to a prolonged quasi-judicial proceeding. It can be anticipated, Judge Madden argues, that if the board proceedings are further formalized, such an inexpensive remedy will no longer be available.

One solution might be for the boards to offer to any contractor who so elects an alternative, informal proceeding without the resulting decision being considered "final and conclusive." If the contractor were satisfied with the decision, that would be the end of the matter. If the contractor were not satisfied, he would be entitled to a second bite at the apple-that is, a formal appeal which, of course, would be subject to the finality requirement. An optional non-final proceeding along such lines might preserve the present two-fold purpose of the disputes procedure as a settlement device and a quasi-judicial process. ${ }^{71}$

the board decision must be rendered by the individual who presided at the hearing." The record discloses that the Board member who conducted the hearing was not one of the panel of three who signed the opinion.

${ }^{88}$ As noted above, supra note 50, 5 U.S.C. $\$ 94$ (I958) does not appear to meet the contractor's nceds.

${ }^{\circ \theta}$ President Kennedy's recent Administrative Conference has made a generalized recommendation which might be a starting point. Recommendation No. I2 provides that:

"Departments and agencies of the Federal Government engaged in procurement, which have established internal appellate procedures and entities (i.e., boards of contract appeals, boards of review, etc.) which render decisions or opinions concerning disputes under contracts of departments or agencies, [should] afford contractors, in cases where a substantial issue of fact is material to the decision or opinion, the opportunity to know and contest in the appellate proceedings the evidence which supports the position of the contracting officer of the department or agency, and establish and publish appropriate procedures to this end where they are not presently provided." Selected Reports of the Administrative Conference of the United States, S. Doc. No. 24, 88th Cong., Ist Sess. 43 (1963).

${ }^{70}$ Madden, Bianchi's Ghost, 16 AD. L. Rev. 22 ( 1963 ). Judge Madden wrote the ill-starred opinions of the Court of Claims in Wunderlich, Volentine, and Bianchi.

${ }^{71}$ A somewhat similar proposal for informal procedure has been made by the sponsors of S. I 663 presently under active consideration by the Subcommittee on Administrative Practice and Procedure of the Senate Committee on the Judiciary, see Committee Print, 88th Cong., Ist Sess. $\$ 5$ (c) (I963). 
Does Bianchi Foreclose Genuine Judicial Review?

Some practitioners fear that Bianchi's denial of a de novo judicial proceeding will in fact close the door to judicial review as effectively as did the Wunderlich "fraud and fraud alone" test over ten years ago. Granting the premise that Wunderlich effectively barred the court to an aggrieved contractor, does it follow that Bianchi will have the same restrictive result?

It is undoubtedly true that there is no substitute for seeing and hearing the witnesses under close examination; the credibility and demeanor of witnesses (and counsel) rarely filters through a cold record. On the other hand, properly read, the statutory language of the Wunderlich Act offers the court fairly broad latitude. The act establishes four standards in addition to Wunderlich's strict fraud test. The standard, "so grossly erroneous as necessarily to imply bad faith", is one with which the Court of Claims had considerable experience prior to Wunderlich. "Arbitrary" and "capricious" are phrases borrowed from section ten of the Administrative Procedure Act. The fifth standard, "not supported by substantial evidence" is, of course, the broadest, and at the same time a familiar, standard in the judicial review lexicon. It is the standard which courts of appeal apply almost daily to decisions of independent regulatory agencies. It is not intended that a court must uphold a board's decision if there only exists in the record "some supporting evidence."72 In fact the Administrative Procedure Act and the National Labor Relations Act, the two statutes relied on by the House Report, suggest the very opposite. ${ }^{73}$ As Professor Jaffe suggests, "it is at least arguable that, properly conceived, substantial evidence means, and should always have meant substantial on 'the whole record' ...."7t The Court of Claim itself recognizes "the congressional directive" that, when it exercises its appellate powers under the Indian Claims Commission Act, ${ }^{75}$ it must "consider the record as a whole, and not only a particular piece of evidence in isolation."

Nor need the Court of Claims defer to the board's findings as federal courts

${ }^{72}$ See Madden, supra note 70, at 31: "Must a court, though it is firmly convinced from a consideration of the whole record that the departmental decision is wrong, still refuse relief because there is some evidence to support it?" See Dean Stason's similar charge, Stason, "Stubstantial Evidence" in Administrative Law, 89 U. PA. L. REv. r026, ro49-50 (I94I).

${ }^{73}$ Sec. $10(c)$ of the Administrative Procedure Act provides that the reviewing court shall set aside agency action "unsupported by substantial evidence," and that "in making the foregoing determinations the court shall review the whole record or such portions thereof as may be cited by any party. . . " As for the National Labor Relations Act, while the original Wagner Act provided that "the findings of the Board as to the facts, if supported by evidence, shall be conclusive," the Taft-Hartley Act amending the Wagner Act provided that "the findings of the Board with respect to questions, of fact if supported by substantial evidence on the record considered as a whole shall be conclusive." Jaffe, Iudicial Review: Question of Fact, 69 HARv. L. Rev. I020, I025 (I956) [footnotes omitted]; see also Universal Camera Corp. v. NLRB, 340 U.S. $474,487-89$ (I95I).

${ }^{74}$ Jaffe, supra note 73 , at ro25. On the remand of Bianchi from the Supreme Court the trial commissioner found the Board's decision lacked substantial evidence reviewed on the whole record in terms of the Universal Camera doctrine, Bianchi v. United States, Ct. Cls. No. 446-54, filed Nov. 4, r963.

${ }_{70} 60$ Stat. 1054 (1946), 25 U.S.C. $\$ 70(\mathrm{~s})$ (I958).

${ }_{70}$ The Spokane Tribe of Indians et al. v. United States, Appeal No. 5-62, decided Oct. II, I963, pp. 6-7, citing Universal Camera Corp., stspra note 73. 
of appeal do with respect to the expert findings of independent regulatory agencies, for in this case the Court of Claims is a tribunal "presumably equipped or informed by experience to deal with a specialized field of knowledge."77 Employed by conscientious, intelligent judges, the "substantial evidence" test should afford contractors a thorough and fair review of a record made by a contract appeal board. It need hardly be added that a court can only give such an "on the record" review if the record has been properly and fully made and protected against ex parte attack.

\section{The Curtous Role of the Comptroller General}

One cannot conclude an attempt to analyze the impact of the Bianchi decision without taking into account the role played by the General Accounting Office (GAO) in the resolution of government contract disputes.

As congressional watchdog of the public purse, the GAO, while not a party to, has an overriding interest in, every government contract. ${ }^{78}$ This interest was prominently displayed in the course of the Wunderlich legislation. There the Comptroller General insisted that his basic power to settle and adjust claims by and against the United States under section 305 of the Budget and Accounting Act of $\mathrm{I} 92 \mathrm{I}^{79}$ be restored at least to its pre-Wunderlich status. In fact, the GAO's consent to enactment of the Wunderlich Act in its final form (the so-called Comptroller General's bill) was conditional on the inclusion of some explicit legislative history to preserve the GAO's prerogatives in this area. ${ }^{80}$

Prior to the Wunderlich decision, the GAO could only reverse the government's contracting officer (or board) for fraud or gross error implying bad faith. ${ }^{81}$ It was suggested at the time of the House hearings that the addition of the "substantial evidence" test would enlarge the GAO's power to reverse a favorable board decision to the detriment of the contractor and the banks and sureties who rely upon him. ${ }^{82}$ Since the passage of the Wunderlich Act the GAO has on occasion asserted its authority to reverse a contract board decision if in its opinion it was "arbitrary" or "capricious" or lacked "substantial evidence" from the government's standpoint, and on at least two occasions it has been upheld by the Court of Claims. ${ }^{83}$

77 Universal Camera Corp. v. NLRB, 340 U.S. at 488.

${ }^{78}$ See Schultz, supra note 4 , at $230,242$.

${ }^{79} 42$ Stat. 23 (I92I), 31 U.S.C. $\$ 71$ (1958).

${ }^{80}$ See House Report 6-7:

"The proposed legislation, as amended, will not add to, narrow, restrict, or change in any way the present jurisdiction of the General Accounting Office either in the course of a settlement or upon audit, and the language used is not intended either to change the jurisdiction of the General Accounting Office or to grant any new jurisdiction, but simply to recognize the jurisdiction which the General Accounting Office already has."

${ }^{81}$ Prior to the Wunderlich Act, the Court of Claims consistently refused to permit the GAO to upset a final decision favorable to the contractor on any other ground, sce United States v. Mason \& Hanger Co., 260 U.S. 323 (1922). For a collection of the unbroken line of cases from I922 to I95I, sce Braucher, supra note 8 , at 489 D.Ir6.

${ }^{82}$ House Hearings, supra note 12, at I08-13.

${ }^{83}$ Northrop Aircraft Inc. v. United States, I27 F. Supp. 597 (Ct. Cl. 1955); Associated Traders, Inc. v. United States, 169 F. Supp. 502 (Ct. Cl. 1959), where the Comptroller Gencral had refused to follow 
As recently as Spring $\mathrm{xg} 63$, the Comptroller isssued a directive to all executive agencies that any release or other contractual instrument entered into as a result of an appeal board decision under the disputes clause must contain a provision to the effect that the instrument is not binding on the government if the decision is subsequently found to violate the standards set forth in the Wunderlich Act. ${ }^{84}$ This strongly-worded directive was occasioned by a settlement and release the Air Force entered into after an important ASBCA decision, the effect of which was to foreclose review by the GAO. ${ }^{85}$

It can thus be seen that the GAO continues to adhere to the view that its authority to review appeal board decisions is commensurate with that of the courts. Very recent evidence of this position is found in a Comptroller General's decision of July I, I963, in which the GAO refused to consider evidence which had a material bearing on the question of the government's liability (whether the government had waived a termination for default) for the reason that the evidence had not been presented to the ASBCA, as required by Bianchi. ${ }^{86}$

Thus it appears that the purported advantage the GAO offers a contractor to have a second (optional) review by another government agency before proceeding to court (this review now being restricted to the board record under Bianchi) is offset by the serious disadvantage under which a contractor labors should the GAO decide to upset a board decision favorable to him because it fails to satisfy the Wunderlich Act's standards. Unquestionably the contractor gives up some important common law rights and remedies when he agrees to the inclusion of the standard disputes clause. By agreeing to "diligently proceed with the work as directed" and to exhaust his administrative remedies, he gives up his right to suspend work and sue for breach or defend suit on the ground that the other party has rescinded the contract. As a reasonable quid pro quo it is arguable that the contractor should be entitled to an appeal to a disinterested board and a final decision which cannot be upset by another government agency. While the GAO is not a party to the contract, it is part of the government and it seems unjust that it should refuse to recognize the bargain the government has struck which includes a finality clause placing serious limitations on the contractor's basic rights and remedies.

the decision of the ASBCA, upholding the contracting officer's assessment of the excess costs of a repurchase of material; in upholding the Comptroller General, the court held the Board's decision not binding because it involved a question of law.

${ }^{84}$ Comptroller General's Op. No. B-r25096, 3r U.S.L. Weer 2568 (U.S. April 30, I963). In an opinion issued Sept. 9, 1963 , the Comptroller clarified his directive to say that it was not intended to apply to ordinary contract modifications, supplemental agreements, and the like, entered into prior to a Board decision. C.G.'s Op. No. B-125096, 6 CCH Gov't Cont. Rer. f 72,260 (1963).

${ }^{86}$ See C.G.'s letter B-125096, April 30, I963, addressed to the Congress, enclosing a report wherein the GAO claimed the Air Force had waived a claim for approximately $\$ 3$ million "because of an unreasonable decision by the ASBCA."

${ }^{80}$ C.G. letter B-150515, dated July $x$, I963, addressed to Seaview Electric Company, Inc.:

"In the light of the decision of the Supreme Court in United States v. Bianchi, decided June 3, 1963, we believe our review of the Board's decision must be limited to the record before the Board." (P. 5.) 


\section{CoNCLUSION}

Dissenting in Wunderlich, Justice Jackson said: "But one who undertakes to act as judge in his own case or, what amounts to the same thing, in the case of his own department, should be under some fiduciary obligation to the position which he assumes." 87 Essentially, the development in the appeal boards of a strong sense of "fiduciary obligation" is the basic problem posed by Wunderlich and Bianchi.

While prior to Bianchi the Court of Claims used a combination trial-appellate procedure to review contract board decisions, Bianchi (with certain exceptions which have been noted) now restricts the court to a purely appellate function in this regard. ${ }^{88}$ Consequently, if a contractor is to have his day in court, he must have it before the Board. This means that the contractor must be prepared to obtain and introduce all his evidence in the board proceeding, and at the same time that the Board's procedures must be modified to make this possible.

Even so, there is a serious risk that board procedures may become so "judicialized" that they deprive the contractor of a speedy, inexpensive but effective informal temedy. As a solution it has been suggested that the procurement authorities offer a contractor an optional informal proceeding, specifying that the resulting decision would not be considered "final" under the disputes clause. If the present small percentage of appeals taken to the courts from the boards is a trustworthy indication, a large number of the present volume of appeals could be settled in this manner. At the same time under this proposal a dissatisfied contractor would be entitled to go through a formal proceeding and obtain a decision which would have finality and be appealable under the Wunderlich Act.

Of course, it would be possible to abandon the disputes procedure and permit the contractor to go directly to court from an adverse decision of a contracting officer. Before taking this step, however, one must weigh its considerable impact both on the government's procurement program and on the functioning of the Court of Claims. Undoubtedly, abolition of the disputes machinery would reduce the agencies' opportunity for expeditious and inexpensive settlements of disputes. Moreover, while there are no statistics on the total number of contract appeals decisions handed down each year, the largest of the dozen boards, the ASBCA disposes of an average of $700-800$ cases a year. ${ }^{89}$ Assuming that the total volume of cases disposed of by all boards is on the order of 1,500 cases annually, one can appreciate how such a potential additional caseload would affect the Court of Claims,

${ }^{8 \pi} 342$ U.S. at 103.

${ }^{88}$ Professor Ralph Nash of the George Washington University Law School has suggested that Bianchi makes the trial commissioner's role somewhat anomalous. He asks whether we now have a two-court appellate review of the administrative record and, if so, isn't this wasted motion? Perhaps the relationship between the Court of Claims and its commissioner approximates that between the Court of Appeals and a federal regulatory agency: the commissioner reviews the contract appeal board record much as the agency reviews the hearing examiner's record.

${ }^{80}$ See House Hearings, stupra note 63 , at 868 . Information from the ASBCA confirms the currency of these statistics. 
which disposed of eighty-four contract cases during the year ending September 30 , $1963^{.00}$

Or, it would be possible, as Judge Madden has suggested, ${ }^{91}$ to repeal the Wunderlich Act and, while not abandoning the disputes procedures, provide that appeal board decisions have no binding effect on the courts. Presumably Judge Madden's proposal would not preclude the procurement agencies from requiring contractors to exhaust their administrative remedies, and a considerable number of cases could be disposed of administratively. Further, since the Court of Claims would return to its former practice of having a de novo proceeding, which would now in no respect be bound by the record made before the board, the board proceeding could be as informal as desired. Judge Madden's proposal thus has a certain attraction.

Several points, however, should be noted. First, "finality" is presently a one-way street. Other than an occasional veto by the GAO, the contractor is the only one who has a practical appeal from a board decision; the decision is final against the procurement agency. But if "finality" is eliminated, could the contractor rely on a favorable board decision? Probably not, unless it were subsequently reduced to a settlement and release (a practice which the GAO has recently prohibited). Such non-finality would have an adverse effect not only on the contractor but on his subcontractors, sureties, banks, and others upon whom he relies and who rely upon him. Second, would the procurement authorities wish to continue the disputes machinery (the ASBCA now has twenty-five full-time members; the Corps of Engineers Board has nine), ${ }^{82}$ if they could be taken into court for a full scale de novo hearing; Congress might find it uneconomical to continue the boards if their status were no better than justice-of-the-peace courts. Consequently, it would seem that steps to abolish the disputes procedure or to eliminate its finality, as Judge Madden suggests, should not be lightly taken.

Finally, it might help one's perspective to focus on the true nature of the modern government contract. There is reliable testimony that this contract is becoming less and less a bargain and more and more a book of regulations. A month after the Supreme Court decided Bianchi, the Court of Claims held that the government could rely on a standard "termination for convenience" clause even though the agency which drafted the contract in issue had omitted this clause from the standard provisions contained in the contract. ${ }^{33}$ Recognition that the contractor is significantly subject to federal procurement laws and regulations regardless of the bargain he may assume he has struck suggests he should be afforded the rights of

\footnotetext{
${ }^{00}$ Information obtained from the Clerk of the Court of Claims. The total number of cases disposed of by the court during the same 12-month period was 468 . As of Sept. 30, 1963 out of the total of 1,489 pending cases, 350 are contract cases, almost all of which are triable.

${ }^{01}$ Madden, supra note 70.

${ }^{2}$ Ablard, supra note 56, at 66-67.

${ }^{03}$ See G. L. Christian and Associates v. United States, Ct. Cl. No. 56-59, decided July 12, 1963, cert. denied, 375 U.S. 954 (1963).
} 
any "aggrieved person" when those laws or regulations adversely affect his interests. This, of course, further suggests that, while he may be required to exhaust his administrative remedies, he should be guaranteed "due process" at some administrative stage before his claim is finally decided, and full judicial review on the whole record thereafter. Only in this way will Justice Jackson's sense of "fiduciary obligation" be developed. 